\section{Research Article}

(C) 2021 Brian K. Majola. This is an open access article licensed under the Creative Commons Attribution-NonCommercial 4.o International License (https://creativecommons.org/licenses/by-nc/4.o/)

\title{
Support Extended to Women Ward Councillors by Stakeholders in South Africa
}

\author{
Brian K. Majola \\ Faculty of Management and Law, \\ School of Economics and Management, \\ University of Limpopo, South Africa
}

DOI: https://doi.org/10.36941/jesr-2021-0053

\begin{abstract}
The paper aims to explore how culture, family and community-women have shaped women councillors' representation and participation in South Africa. It investigates the extent to which women ward councillors are gaining support from their male counterparts; other women councillors irrespective of political affiliation when women-related issues are raised in council meetings. The paper identifies reasons contributing to the non-support by key stakeholders when women-related issues are raised and when performing their duties. Post-1994 in South Africa, women's participation in politics is still a struggle. The number of women ward councillors have been fluctuating since the local government was reformed between 1995/96. Ward councillors are elected by local communities to represent their respective wards, to be accountable to the community that elected them. The paper is exploratory and qualitative in nature. It focuses on 104 Ward and Proportional Representative (PR) councillors from local municipalities in KwaZulu-Natal and Eastern Cape Provinces. Faceto-face and telephonic interviews were employed. Findings were analyzed using content analysis and themes were induced from the data. The paper revealed that culture is gradually changing due to laws introduced. Also, family support depends on a woman marital status and family involvement in politics. However, males did not support women-related issues, but women ward councillors supported each other irrespective of political affiliation on gender issues. Community-women support councillors through women's groups and community structures. The factors contributing to the non-support of gender-related matters include women competing with each other and political party influence.
\end{abstract}

Keywords: ward councillors, women support, stakeholder theory, gender issues, local government

\section{Introduction}

For the past five decades, women have been fighting for recognition and equal representation in all decision-making structures, especially in democratic countries. Women constitute half the world's population, but they account for less than a quarter of the membership of national parliaments globally (Iyer \& Mani, 2019). Figures for most countries still fall short of the target set by Southern Africa Development Communities (SADC) to have 50\% of women in decision-making positions (SADC, 2019). Morobane, (2014) argues that a lack of adequate support structures to rectify existing codified institutions to include women in political leadership and achieve gender equality in global politics has been the challenge. Post-1994, South Africa introduced laws that ensured equal representation of 
women in all structures and institutions guided by ratified UN Conventions and Recommendations. Women ward councillors are now at liberty to raise women-related issues which can be supported by internal and external stakeholders.

The challenge South Africa is facing is the number of women ward councillors that has been fluctuating since the local government was reformed in 1995/6 (Majola, 2020). Women ward councillors might not contest elections again due to lack of support from the family, communities, political parties, municipalities, and other key stakeholders. The next local government elections are scheduled for 2021 in South Africa. However, there is limited or no research focusing on key internal or external stakeholders supporting women ward councillors in executing their duties and in addressing women-related issues. The paper aims to explore how culture, family and communitywomen support have shaped women councillors' representation and participation at local government level. It investigates the extent to which women ward councillors gain support internally from their male counterparts when women related issues are raised in council meetings. The paper examines the extent to which women councillors support each other irrespective of political affiliation when womenrelated issues are raised in council meetings. Lastly, the paper identifies the reasons contributing to the non-support of women related issues at the local government even after twenty-six years of democracy.

\section{Legislative Framework Supporting Womens' Participation in Politics}

\subsection{International Agencies Role in Supporting Women in Politics}

The promotion of gender equality and the empowerment of women is a global policy priority across countries and development institutions (Piazza \& Diaz, 2020). The Convention on the Elimination of Discrimination Against Women (CEDAW) (1979) calls on states to deal with the elimination of discrimination against women in all spheres of life (Democracy Reporting International, 2011). Furthermore, the UN recognised the importance of non-governmental organisations (NGOs) as key stakeholders in advancing the implementation of the Beijing Declaration and Platform for Action (UN CSW, 2009). Besides, when UN Women was established in 2010, stakeholders such as civil society, academia, governments and other development organisation were consulted. UN Women is responsible for capacitating women for political participation and educating them on gender equality. The African Union (AU) then launched the African Women's Decade, 2010-2020 to accelerate the realisation of regional and global commitments to the empowerment of women through a top-down and bottom-up approach which is inclusive of grassroots participation (Kamau, 2011). The Southern African Development Community (SADC) Protocol on Gender and Development (2008) devoted South Africa to recognise the rights of women as unchallengeable rights. This has led to more women occupying political positions. The global increase of women's political representation has occurred alongside the increased implementation of quota legislation (Clayton, 2016; Rosen, 2017).

\subsection{The Constitution (RSA) and Local Government Related Prescripts}

The Constitution of the Republic of South Africa (1996), section 9 promotes gender equality and ensures that women enjoy equal rights. Section 21 states that one can be elected as a councillor irrespective of race, gender or level of education. Furthermore, section 22 provides for an equal number of councillors representation from various political parties proportionally. In Chapter 7, section 152, the Constitution places an obligation on the local government to encourage the involvement of communities and community organisations in matters of local government (CLGF, 2017).

The White Paper on Local Government of 1998 (as amended) (White Paper) states that municipalities should ensure that there are representatives from different groups which were previously marginalised who can contest the elections, including women. It also allows municipalities to assess the impact of their strategies on women and ensure that the needs and interests of women 
are incorporated into municipal planning processes.

The Municipal Structures Act No. 117 of 1998 (as amended) request for fifty percent of women candidates on political party lists. The Act distinguishes between types of councillors, the Proportional Representative (PR) Councillor, a councillor elected under section 22(1) (a) and Ward Councillor, a councillor elected in terms of Schedule 1 of the Act to directly represent a ward. The Municipal Systems Act No. 32 of 2000 (as amended) makes provision for local communities to participate in the affairs of the municipality through political structures and ward committees. There are prescripts supporting women ward councillors as key stakeholders working with other stakeholders at the local government level.

\section{Theoretical Literature on Stakeholders at Local Government Level}

\subsection{Definition of Stakeholders}

Freeman's (1984) defines a stakeholder as any group or individual that can affect or is affected by the achievement of the organisation's objectives. Furthermore, Bryson (1995), defines a stakeholder as any person, group, or organization that can place a claim on an organization's attention, resources, or output, or is affected by that output. Stakeholders play different roles and with their different interests, capacities, resources and potential roles, are not equally involved in the process (Diplomatic Academy, 2018). Stakeholders can either be internal or external (Amadi, Carrillo \& Tuuli, 2018); their objectives are often poorly understood (Pawlowska, 2004) and conflict of interest between stakeholders can arise (Snider, 2005; Rose, Flak, \& Seabo, 2018).

\subsection{The Stakeholder Theory}

The paper adopted that stakeholder theory which was introduced by Professor Freeman (1983) based on the assumption that businesses can only be considered successful when they deliver value to the majority of their stakeholders. According to Gregory, Atkins, Midgley \& Hodgson (2020), stakeholder theory emanates from its focus on the often overlooked sociological question of how organisations affect society. However, stakeholder theory has been utilised in various fields in the past decades especially in the organisational strategy, economics, public policy, social and political issues. Rowley (1997) argued that stakeholder theory does not only require one to understand the influence of stakeholders on an organization, but also how these organizations respond to these influences. Effective local government leadership is the kind of leadership that primarily embrace inputs and contributions made by stakeholders (Mkhize, 2018). However, one may ask, how are family and cultural influences dealt with by the local authorities in supporting women councillors before and during the election as well as when performing their duties.

Local government is all about bringing government closer to the people (ETU, 2020) and councillors are the first line of contact regarding service delivery in their community. When ward councillors have a relationship with the community based on trust, credibility, transparency and respect, they can detect and attend to community problems at an early stage; thus, they can respond effectively to them (Molefe \& Overtone-de Klerk, 2019). For women ward councillors to gain support from other stakeholders such as the municipalities, political parties and other agencies, they must engage and sensitise internal and external stakeholders on gender issues. That is where stakeholders with different interests from large and diverse groups, unequal as they are, become key players in the stakeholder theory. Therefore, it is crucial to understand the role of ward councillors and committees at the local government level.

\subsection{Internal and External Stakeholders}

Local government can work with different stakeholders such as community leaders, traditional leaders, 
religious leaders, business, labour, youth, women and civil society and create a harmonious existence of all South Africans when everyone contributes to the success of the municipality and its people (Mkhize, 2018). Identifying stakeholders at the local government level is not an easy process as individuals and group interests vary. However, for this paper key stakeholders are municipal and traditional councils, political parties, religious leaders, families and cultural influences, community organisations and women's groups. These stakeholders can work together to support women ward councillors on addressing gender issues and when executing their local government duties.

\section{Support by other Stakeholders}

\subsection{Religion and Culture Support}

South Africa has been a very religious country since the arrival of the missionaries a few centuries ago (South African History Online, 2019). Like in many non-western societies, religion influences formation, negotiation, and transformation of gender relations at work and in society (Predelli, 2004; Kamla, 2019: 53). The churches have provided spaces for women however, at the same time has undermined some of the respect with which women were regarded in traditional culture (Palmieri \& Zetlin, 2020). According to the Bible, men are regarded as superior because God ordained them to be superior and women may not be leaders because of their fragility (Wood, 2019). This situation has forced women to seek approval from male church leaders to hold positions in their communities. Therefore, priests and pastors became other key stakeholders in supporting women before and after their election into positions.

According to Wood (2019), culture is a socially perceived set of characteristics that distinguish between male and female and determine what is expected and what the allowed values between males and females are. South Africans are a culturally diverse community where women have to understand their space in the family and community as well as during cultural functions. Like in any community, culture and socialisation also affect women's confidence and their chances of being elected into leadership positions. Gender-role socialization and low self-confidence are key reasons why women leaders consistently under-predict their performance (Sturm, Taylor, Atwater, \& Braddy, 2014). In rural places, women's political participation in elections and tenure in the office can be influenced by the relations the ward councillor has with chiefs and religious leaders. Although prescripts have been promulgated to liberate women in South Africa, the religion and culture values/practices are challenges that can enable or hinder the success of women ward councillors in South Africa.

\subsection{Family Support}

Family commitment constitutes a major source of concern for women (Rosenbluth, Kalla \& Teele, 2015). Women face opposition from family and community if they decide to enter politics (Martins, 2013). Aryan (2012) argued that gender inequalities and different limitations are imposed on women by family structures and society. According to Mugisha (2000), women are not enjoying any support from men in their homes and communities to participate in politics especially at the local government sphere. Furthermore, if the woman is young, single and Black, she has little input in the family affairs due to her marital status. Women's lack of voice within the family and restrictions on their mobility hinder their participation (Iyer \& Mani, 2019). Several women who have been leading or who have been prominent in their countries have been wives and or daughters of male politicians (Franceschet, 2005; Majola, 2015). If one comes from a political family (wife or daughter of a male politician) support from family is guaranteed. Rosenbluth, Kalla \& Teele, (2015) added that only women with supportive families run for office, whereas men are likely to run despite discouragement from their families. Support to enhance individual women's capabilities and empowerment are important for women's collective action, as a woman's ability to participate in collective action is linked to her power at the family level, including concerning family income, assets and decision-making (Care Nederland, 2018). However, 
over the past decade, family structures and gender roles have shifted with women enjoying their human rights as independent citizens. Therefore, women ward councillors' family support is crucial before and during their term of office.

\subsection{Community Organisations and Women's Groups Support}

Community organisations or civil society are other stakeholders that support women in their political careers particularly at local government level. Women have organised themselves and formed movements to put pressure on governments to recognise their rights and interests. Civil society activism can provide an important route for women to build a political profile and enter formal politics without having to progress through political parties (Care Nederland, 2018). Through participation in community projects, structures and women's groups, women get recognition and trust from community members. When running for office and once elected, women still need greater support networks from civil society (Vijeyarasa, 2020), community structures and other community-women to successfully execute their duties as councillors. In South Africa, most women were involved in community projects and protests pre-1994 and recognised by their communities. However, this changed after the first non-racial democratic elections as those women moved to the national level and overseas donors for community projects became limited. Brandsen, Trommel \& Verschuere (2017) argued that civil society should be reinvented and given a new position in society. Women ward councillors should continue to gain support from community organisations and projects.

\subsection{Traditional Council and Leadership Support}

The White Paper on Traditional Leadership provides for the recognition of traditional communities and traditional leaders in South Africa. The Traditional Local Government Framework No. Act 41 of 2003 allows for the representation and participation of women in all decision-making processes by the traditional council (Fikeni, 2008). Beall (2005) (in Steimanis, Hofmann, Mbidzo, \& Vollan, 2020) argues that women are particularly defenceless under the traditional arrangement as their rights are limited due to marital status and lack of access to certain resources. In everyday rural life, gender roles and ideas of leadership are inevitably intertwined with cultural values, norms, and practices. To maintain their power, elites such as traditional leaders may encourage their wives and relatives or women who are more likely to adhere to traditional norms to serve on the local council (Steimanis et al, 2020). However, as key stakeholders and custodians of culture, traditional leaders can facilitate the creation of protective cultural environments in their communities (Ndebvu, 2020). Therefore, this makes traditional council and leadership key stakeholders in supporting women ward councillors when performing their duties.

\subsection{Municipal Council Support}

In South Africa, ward and PR councillors support function is located in the Office of the Speaker who provides general support and attend to individual needs of councillors including their welfare. In addition, the Public Participation Section assists councillors with the performance of community duties. All councillors are provided with tools of the trade, in terms of the Remuneration of Public Office Bearers Act No. 20 of 1998: Determination of Upper Limits of Salaries, Allowances and Benefits of Members of Municipal Councils. According to EThekwini Municipality (2015) support is provided when councillors are performing duties such as attending ward and community groups meetings; conferences, seminars and courses. However, the council's support is limited for women ward councillors when dealing directly with community members including their protection. The biggest problem facing councillors is their literacy level, as some councillors cannot apply their minds to the documents written by municipal officials (StatisticsSA 2011). Therefore, the capacity and the potential of the individual to be fit enough to represent the community, plays an important role (Afesis, 2016). As a result, municipal councils become key stakeholders in determining the success of women ward councillors. 


\subsection{Political Party's Support}

Women's organisations in the political parties play an important role in mobilising women candidates and supporting them once nominated (Lovenduski, 2002). Nonetheless, political parties often do little to prepare and support women for office once elected. Once elected, women often find the practical difficulties of council work overwhelming. Female politicians receive fewer private donations than their male counterparts and rely relatively more on party sponsorship and support (Rosenbluth et al, 2015). As a result, commitment to a political party inevitably means that gender issues take second place to party loyalty (Sales, 1997:177-179). This can hinder support provided to women ward councillors while addressing gender issues during municipal council meetings. A study conducted by Palmieri \& Zetlin (2020) found that family, church and traditional leaders, and communities, can be more powerful than political parties in influencing women councillor nomination and election in the Pacific Region because political parties at the local level in that region are disorganised in such a way that they recruit women from church. Even in South Africa, the role of political parties as key stakeholders in supporting women ward councillors on gender issues and when performing their duties cannot be overemphasised.

\section{Women-Related Issues and Gender Interests}

Thomas (1994) maintains that when the number of women increases in different structures, women would be in a position to form alliances to promote their interests. However, women's interests are not homogenous (Celis \& Childs, 2012). Kalra \& Joshi (2020) argue that women-related issues vary and changes over time. Furthermore, women's interests are not determined solely by gender, but are given further content by age, class, race, sexuality, generational, ethnicity, and religion (Franceschet, 2005; Collins \& Chepp, 2013; Hancock, 2014). Ward councillors are elected by local communities including women to represent their respective wards. However, once elected, ward councillors have to be accountable to the community that elected them. Women councillors need to be accountable to issues raised and ensure that fairness and objectivity is maintained in prioritizing issues at local government level. Women ward councillors need support from other women as they are key stakeholders in determining their success in addressing women-related issues within the council and performance of their duties at local government level.

\section{Women Versus Men}

Men within and outside the council are other key stakeholders in supporting women ward councillors in the execution of their duties. Research shows that women are particularly likely to nominate other women as role models, particularly if these women identify highly with their gender (McLaughlin, Silvester, Bilimoria, Jané, Sealy, Peters, Möltner, Huse, \& Göke, 2018). Aryan (2012) argues that men who occupy high positions feel threatened by women; they see women as their competitors and rivals and do not welcome these new competitors. Therefore, the male counterparts must support women ward councillors when gender issues are raised and when performing their duties. Iyer \& Mani (2019) pointed out that increasing women's engagement and representation in the political sphere can improve the welfare not just of women, but also of society.

\section{Research Methods}

The paper adopted an exploratory research design and is qualitative in nature. It focuses on six local municipalities from KwaZulu-Natal (KZN) and the Eastern Cape (EC) Provinces. In KZN, 78 councillors from EThekwini Metropolitan Municipality and four local municipalities under UMgungundlovu District were involved namely, uMsunduzi, uMngeni, uMshwati and uMkhambathini Local Municipalities. In the EC Province, 26 councillors from Mzimvubu Local Municipality participated. There were 23 women ward councillors; 37 male ward councillors, 30 women PR councillors and 14 
male PR councillors. In-depth semi-structured interviews were adopted using face-to-face and telephonic interviews due to the geographic dispersion of respondents. Data was collected using secondary information such as annual municipal reports, national policies and local government prescripts and other publications. Content analysis was used and themes were induced from the data. Data was presented in the form of tables. The gatekeeper's letter was obtained from all targeted municipalities and confidentiality was communicated to respondents.

\section{Results and Discussion}

The results were analysed and presented using tables which list the themes and the frequency of the responses. To determine the extent to which women ward councillors are gaining support from other stakeholders (internal and external), five questions were asked. In this paper, all the respondents (men and women) shared their experiences.

\subsection{Culture and Family Support}

Respondents were first asked to state how culture and family support shaped women councillors participation and representation in politics as councillors at local government. Some respondents responded to both culture and family, and some reported on only one. Therefore, the frequency of responses might be more than the number of respondents in the paper. In respect of cultural support (Table 1), twenty-one respondents ( $15 \%)$ indicated that culture is gradually changing. Besides, five per cent $(n=7)$ of the respondents reported that culture is changing only because the laws of the country have changed.

Respondent 12 stated that "we have been led by men and traditional leaders for too long, but the constitution has changed that." This response points to the UN and national prescripts that South Africa has ratified and promulgated to address gender inequalities in all spheres of life. The new Constitution (Republic of South Africa), allows one to be elected as a councillor irrespective of race, gender or level of education (s21) and promotes gender equality (s9). The White Paper (1998); Municipal Structures Act (1998) and Municipal Systems Act (2000) encouraged the equal representation of women in all structures where decisions are made. As a result of these laws, more women are elected as ward and PR councillors.

Table 1: Culture and Family Support for Women

\begin{tabular}{|l|l|c|}
\hline $\begin{array}{l}\text { Culture/Family } \\
\text { Support }\end{array}$ & Themes & $\begin{array}{c}\text { Frequency of } \\
\text { Responses }\end{array}$ \\
\hline Culture & Culture is gradually changing & 21 \\
\hline & Women need buy-in from traditional leaders and or religious leaders & 12 \\
\hline & Women are still treated as minors & 9 \\
\hline & Changing because of the changing laws & 7 \\
\hline & Culture does not allow women to hold certain positions & 5 \\
\hline & More opportunities for 'white culture' than 'black culture' & 4 \\
\hline & Depend on family involvement in politics & 23 \\
\hline & Depend on marital status & 18 \\
\hline & Depend on the husband & 15 \\
\hline & Depend on individual background in politics & 9 \\
\hline & Women want to dominate at home & 6 \\
\hline & Depend on the residential area, whether it is urban or rural & 4 \\
\hline
\end{tabular}


Nine per cent $(n=12)$ of the respondents mentioned that the current situation requires women to obtain buy-in from traditional leaders and or religious leaders before and during their term as councillors. Nine respondents $(7 \%)$ indicated that women are still treated as minors concerning cultural practices. Respondent 74 stated that "I was a ward councillor...the priest and church members gave me support and blessings". Beall (2005) argued that women are particularly defenceless under the traditional arrangement as their rights are limited due to their marital status and lack of access to certain resources. Ndehvu (2020) maintians that traditional leaders can facilitate creating protective cultural environments in their communities. It must be noted that most women affected are from rural communities as they need support from traditional and religious leaders before and after their election as councillors.

Five respondents $(5 \%)$ felt that culture does not allow women to hold certain positions in society. Furthermore, four respondents (3\%) were of the view that there are more opportunities for 'white culture' than 'black culture'. In that way, they were differentiating between white women councillors being regarded as having better career opportunities and black women councillors being regarded as loose and rude due to cultural differences. Although the Traditional Local Government Framework No. Act 41 of 2003 allows for the representation and participation of women in all decisionmaking processes taken by the traditional council (Fikeni, 2008), men will take over the power from a woman councillor during community meetings. To avoid this situation, the woman ward councillors must always be accompanied by a male or a group of men. Because of the history of the country, the support given to White women councillors by other stakeholders is different to Black women councillors.

Concerning family support given to women councillors, twenty-three respondents (17\%) indicated that the participation and representation of women depend on the involvement of family members in politics as one can be politically educated at home by her father, brother, husband and other male family members. Respondent 33 stated that "my husband was a politician...when I am not at home my kids will tell people that I am attending a meeting somewhere". Women with supportive families run for office, whereas men are likely to run despite discouragement from their families (Rosenbluth et al, 2015). If one comes from a political family, support from family is guaranteed. Women ward councillors from political families receive support which lessens the pressure when executing their duties. Eighteen respondents (13\%) reported that the woman councillor's support depends on her marital status. Whereas, eleven per cent $(n=15)$ respondents reported that a woman would have to gain the support of her husband before and during her active participation in politics. Respondent 6istated that "I am single and there is no one who asks me questions when I come back late". On the contrary, Respondent 15 stated that "when you are single, they say we cannot be led by a girl when we are married women". Respondent 41 pointed out that her "husband is an ex Member of Parliament and ex-councillor...I have a hundred per cent fantastic support". The responses highlights that being single poses challenges for women ward councillors. Responses further show that the women ward councillor non-support can come from other women. This is affirmed by Martins (2013) who argued that women face opposition from family and the community if they decide to enter politics. Furthermore, Mugisha (200o) added that women are not enjoying any support from men in their homes and their communities to participate in politics.

Seven per cent $(n=9)$ respondents indicated that the participation and representation of women depend on the individual background in politics. Respondent 77 a female, remarked that "because of the background, very few women are politically clued up...they do not know deep politics...because of political education in my home, we debate about politics". The responses show that the level of education and political education is crucial to the successful election and performance of women ward councillors. According to Afesis (2016), the capacity and the potential of the individual to be fit enough to represent the community plays an important role. However, this is in contravention with the Constitution's s21 which allows councillors to be elected irrespective of race, gender or level of education.

Four per cent $(n=6)$ of the respondents mentioned that women who are in politics dominate at 
home, whereas, four respondents (3\%) felt that the area that the family resides in, have an impact. Three respondents (1\%) indicated that they do not know. Respondent 90 said that "it depends on whether it is an urban or rural area...the husband might not support you". One can notice that in rural areas when a woman becomes a councillor she might appear as a dominant partner at home. Alternatively, traditional leaders may encourage their wives and relatives or women who are more likely to adhere to traditional norms to serve on the local council (Steimanis et al, 2020). However, new laws have changed the public opinion regarding gender roles, allowing people to focus on individual needs. In SA, still, there is a lack of support for women due to family situations such as marital status. This is worse if women are young, single, Black and reside in rural areas. However, cultural support due to change in laws has shaped women ward councillor's political participation and their election as councillors in South Africa.

\subsection{Women Support from Other Community Women}

Respondents were asked about the support women councillors gain from other women in their communities. Some respondents mentioned more than one reason. Thirty-two respondents (25\%) reported that support was gained through involvement in community structures and projects and fifteen per cent $(\mathrm{n}=19)$ through joining women's groups. Respondent 33 said, “you have to be involved in community projects". This response affirms Vijeyarasa's (2020) view that when running for office and once elected, women still need greater support networks from civil society. The findings are also in line with Care Nederland (2018) who pointed out that civil society activism can provide an important route for women to build up a political profile and enter formal politics without having to progress through political parties. One can state that women from community organisations and women's groups are key stakeholders in supporting women ward councillors when performing their duties.

However, nineteen respondents (15\%) mentioned that they do not get any support from other women in their communities. Respondent 40 said, "it is very rare to get support from other females...if you are weak they can destroy you". According to the stakeholder theory, women are one of the key stakeholders at the local government level. Mkhize (2018) pointed out that effective local government leadership is the kind of leadership that primarily embrace inputs and contributions made by stakeholders. The responses show that community women as key stakeholders at the local government level are not supporting each other. This is in contravention to McLaughlin et al (2018) view that women are particularly likely to nominate other women as role models, especially if these women identify highly with their gender. The support from other community women would strengthen the performance of women ward councillors.

Thirteen per cent $(n=16)$ of the respondents indicated that support depends on the councillor's attitude and depends on the issue according to seven respondents (6\%). Two respondents (2\%) reported that it depends on councillors' work ethics. Respondent 41 said, "Am a PR councillor, but I address people everywhere, depending on the issues... Indians do not do things on their own". Molefe \& Overtone-de Klerk (2019) pointed out that when ward councillors have a relationship with the community based on trust, credibility, transparency and respect, they can detect and attend to community problems at an early stage; thus, they can respond effectively. From the response above, the women ward councillor would gain full support from other women depending on the attitude, the issue raised and work ethics, irrespective of whether one is a ward councillor or a PR councillor.

Five respondents $(5 \%)$ indicated that councillors gain support from both males and females in the community and receive support from ward committee members according to (3\%) three respondents. Another (3\%) three respondents mentioned that different communities and races may give a woman support based on her race. Ten per cent $(n=12)$ of the respondents felt that the support from other community women is limited, whereas 8 respondents were not aware of any support gained from other community women. Respondent 62 stated that "sometimes they do not support...Indian communities are not interested in issues affecting black communities in the informal settlements...they have their issues". The researcher learned that it was difficult for other respondents 
to respond as they were only female PR councillors with no wards. Their interaction with communities is where and when there was a need or at the request of the council, wards councillors, or community members. They also indicated that interacting directly with community members from a certain ward created tension between ward councillors and them.

The researcher also learned that where there was a male ward councillor, community women would request a female PR councillor to come to their women's group as the male might not be interested in women's issues. One can notice that there is limited support as stakeholder engagement is based on gender. Women ward councillors support is gained through community structures, women's groups, and not from any community-women.

\subsection{Male Counterparts Supporting Women-related Issues}

Respondents were asked about the extent to which male counterparts were supporting women issues raised by women councillors in the municipal council meeting. The majority of the respondents at $47 \%$ $(n=48)$ indicated that there was gender balance in all structures of the council which allowed all matters to be addressed. Respondent 73 stated that "when choosing a structure there must be a balance". Twenty-three respondents (22\%) felt that males do not support gender or women-related issues. Respondent 11 stated that "they want to dominate...we wanted a netball court by the school...no one listened to me because I am a female". Twenty-two (21\%) respondents said it depends on whether or not the idea raised made sense. Eleven respondents $(10 \%)$ indicated that there was no full understanding of gender or women-related issues by their male counterparts. Respondent 38 said, "men would pass remarks and say you now want to do your stuff as if gender is about women". When respondents were asked this question, most of them reported that issues discussed in the council are not gender-based but they focus on the needs of the communities. However, they are raised first within their respective political parties. Commitment to a political party inevitably means that gender issues take second place to party loyalty (Sales, 1997). This has resulted in gender issues not being fully understood by some respondents, especially men. However, when it comes to structures within the council, women are always represented and therefore there is gender balance. Most importantly, the response irrespective of whether from a male or a female, the idea put forward by any councillor must make sense.

\subsection{Women Supporting Each other Irrespective of Political Affiliation}

Respondents were asked whether women councillors support each other irrespective of political affiliation when women-related issues are raised in council meetings. Respondents had different views. Thirty-nine respondents (37\%) reported that women fully support each other, whereas, twenty-five per cent $(n=26)$ were of the view that sometimes women do support each other irrespective of political affiliation. Twenty-eight respondents (27\%) felt that women do not support each other. Whereas, eleven respondents (11\%) stated that they do not know. Respondent 37 stated that "if I do one thing wrong, women are the one who would laugh at you...we do not give support to one another". Kalra and Joshi (2020) contend that women-related issues differ across women and also changes over time. Furthermore, Celis \& Childs (2012) pointed out that women are not a homogeneous group so their interests are not homogeneous. Women, unlike workers fighting for higher wages, are unable to have one common goal at a particular point in time because of their difference in class, ethnic group, race etc. Women's interests are not determined solely by gender, but are given further content by age, class, race, sexuality, generational, ethnicity, and religion (Franceschet, 2005; Collins \& Chepp, 2013; Hancock, 2014). This response shows that there is a lack of a strategic approach to manage stakeholders in the interest of supporting women ward councillors when women related issues are raised in council meetings. 


\subsection{Contribution to Non-Support of Women-Related Issues by Other Women}

As a follow-up question, respondents were requested to state the reasons contributing to the nonsupport of women-related issues by other women within the municipal council. It must be noted that only respondents who mentioned that women do not support each other responded to this question. The majority of the respondents at $67 \%(n=36)$ reported that women compete with each other. Twelve respondents $(22 \%)$ indicated that political party influence has been the contributory factor to women not supporting each other. Some respondents at $11 \%(\mathrm{n}=6)$ preferred not to respond or could not think of any reason. Respondent 59 stated that "political parties are not the same so as their teachings or political education...we sometimes see each other as enemies...it is our politics that need to be changed not only political parties". Some did not respond because they did not see gender as an issue in the council. Some male respondents preferred not to say anything because they did not pay attention to women and their issues. What was discovered was that there were also female respondents who chose not to respond. Women and political parties are key players in the stakeholder theory due to the power they have. With their support, women ward councillors can address women-related issues for the benefit of communities, council, political parties as well as males and females.

\section{Conclusion}

The paper investigated the extent to which women ward councillors are gaining support from other key stakeholders as their number is fluctuating in South Africa. Evidence indicates that culture is gradually changing because of laws introduced, but family support relies on a woman's marital status and family involvement in politics. Although there was gender balance in all structures, males did not support women-related issues. The paper found that women ward councillors do support each other, irrespective of political affiliation on gender issues. Women ward councillors gained support from other community women through women's groups and community structures. Factors contributing to the non-support of gender-related matters were women competing with each other and political party influence. According to the stakeholder theory, these are key players supporting women ward councillors in addressing gender issues and when performing their duties. Internal and external stakeholders such as religious and traditional leaders, political parties, municipal councils, male councillors, family and cultural influences, community-women, community organisations and women's groups should work together as key stakeholders to recruit and support women ward councillors when performing their duties.

\section{References}

Afesis, C. (2016). Government and leadership challenges. [Online] Available: http://www.afesis.org.za/localgovernance/local-governance-articles/297-capacitychallenges-of-ward-councillors-reviewing-the-impacton-accountability.html (o7 September 2020)

Amadi, C., Carrilo, P. M., \& Tuuli, M. M. (2018). Stakeholder Management in PPP Projects: External Stakeholder's Perspective. Built Environment Project and Asset Management, 8(5).

Aryan, K. (2012). The boom in women's education. In T. Povey, \& E. Rostami-Povey. Women, Power and Politics in 21st Century Iran. England: Ashgate Publishing Ltd.

Beall, J. (2005). Decentralising Government and De-Centering Gender: Lesson from local Government Reform in South Africa. Politics and Society, 33(2), 253-276.

Brandsen, T., Trommel, W., \& Verschuere, B. (2017). The State and the Construction of Civil Society. International Review of Administrative Sciences, 83(4), 676-693.

Bryson, J. (1995). Strategic planning for public and non-profit organization. San Francisco: Jossey-Bass Publishers.

CLGF. (2017). The Local Government System in South Africa. [Online] Available: http://www.clgf.org.uk/southafrica (16 August 2020)

Care Nederland. (2018). The Political Participation and Influence of Marginalised Women in Fragile and ConflictAffected Settings. Global Study Report. 
Clayton, A. (2016). Comparative Regional Patterns in Electoral Gender Quota Adoption: A Social Network Approach. KFG Working Paper Series, No. 71. Kolleg-Forschergruppe (KFG), Freie Universitat Berlin.

Celis, K., \& Childs, S. (2012). The Substantive Representation of Women: What to do with Conservative Claims? Political Studies, 6o, 213-225.

Collins, P. H., \& Chepp, V. (2013). Intersectionality. In G. Waylen, K. Celis, J. Kantola, and S. L. Weldon (Eds.). The Oxford Handbook of Gender and Politics, 57-87. New York: Oxford University Press.

Democracy Reporting International. (2011). Report-International Consensus: Essential elements of Democracy. [Online] Available: http://www.democracy-reporting.org/files/essential_elements_of_democracy_2.pdf (17 November 2020)

Diplomatic Academy. (2018). The Role of Stakeholder in Education Aid Effectiveness Principle Level-Practitioner Level. Australian Government-Department of Foreign Affairs and Trade.

EUT. (2020). Local Government in South Africa: Understanding Local Government. [Online] Available: https://www.etu.org.za/toolbox/docs/localgov/webundrstdlocgov.html (15 October 2020)

EThekwini Municipality. (2015). City Government. [Online] Available: http://www.durban.gov.za/City_Government/Pages/default.aspx (17 June 2020)

Fikeni, S. (2008). Conflict and Accommodation: The Politics of Rural Local Government in the Post-apartheid South Africa. Department of Political Science. PhD Dissertation. Michigan State University.

Franceschet, S. (2005). Women and Politics in Chile. United States of America: Lynne Rienner Publishers.

Freeman, R. E. (1984). Strategic management: A stakeholder approach. United Kingdom: Pitman Press.

Gregory, A. J., Atkins, J. P., Midgley. G., \& Hodgson, A. M. (2020). Stakeholder identification and engagement in problem structuring interventions. European Journal of Operational, 238, 321-340.

Hancock, A. M. (2014). Intersectional representation or representing intersectionality? Reshaping empirical analysis of intersectionality. In M. Escobar-Lemmon, \& M. Taylor-Robinson (Eds.). Representation: The Case of Women, 41-57. New York: Oxford University Press.

Iyer, L., \& Mani, A. (2019). The road not taken: Gender gaps along paths to political power. World Development, 119, 68-80.

Kalra, S., \& Joshi, D. K. (2020). Gender and Parliamentary Representation in India: The Case of Violence Against Women and Children. Women's Studies International Forum, 82-102402.

Kamau, M. (2011). Statement on Behalf of the African Group. New York: UN General Assembly.

Kamla, R. (2019). Religion-based resistance strategies, politics of authenticity and professional women accountants. Critical Perspectives on Accounting, 59, 52-69.

Lovenduski, J. (2002). The Nordic Model: the example of Finland. In Lovenduski, J., Campell, R., \& Sampson-Jacent, J. Women, Public Life and Democracy: Changing Commonwealth Parliamentary Perspectives. London: Pluto Press.

Majola, B. K. (2015). Women's Representation and Participation in the Era of Decentralisation. University of KwaZulu-Natal, PhD Thesis.

Majola, B. K. (2020). Factors Affecting Women Ward Councillors in South Africa. Journal of Reviews on Global Economics, 9, 366-377.

Martins, B. (1993). Women in Politics: Forms and Processes. New Delhi: Har-Anad Publications.

McLaughlin, H., Silvester, J., Bilimoria, D., Jané, S., Sealy, R., Peters, K., Möltner, H., Huse, M., \& Göke, J. (2018). Women in Power: Contributing Factors that Impact on Women in Organisations and Politics; Psychological Research and Best Practice. Organisational Dynamics, 47, 189-199.

Mkhize, Z. L. (2018). Local Government is Everybody's Business. CoGTA National Assembly, Cape Town.

Molefe, L., \& Overton-de Klerk, N. (2019). Community Perceptions of Ward Councillors' Communication in Service Delivery Protest Areas: The Desirability of a Strategic Communication Approach. Communitas, 24, 1-18.

Morobane, F. (2014). Women grossly under-represented in international politics. [Online] Available: http://www.ngopulse.org/article/women-grossly-under-represented-international-politics (11 August 2020)

Mugisha, M. (200o). Gender and Decentralisation: Promoting women's participation in local councils. [Online] Available: http://www.fao.org/docrep/o03/x609oe/x609oeoo.htm (23 August 2020)

Ndebvu. K. (2020). The Role of Traditional Leadership: An Investigation into the Evolutionary Changes in the Roles of Traditional Leadership in Zimbabwe Since 1980. International Negotiation, Academia. [Online] Available: https://independent.academia.edu/kudakwashendebvu (30 October 2020)

Palmieri, S., \& Zetlin, D. (2020). Alternative Strategies to Support Women as Political Actors in the Pacific: Building the House of Peace. Women's Studies International Forum, 82-102404.

Pawlowska, A. (2004). Failures in Large systems Projects in Poland: Mission (im)possible. Information Systems, 9 , 167:18o. 
Piazza, K. S., \& Diaz, G. (2020). Light in the midst of chaos: COVID-19 and female political representation. World Development, 136, 105125 .

Predelli, L. N. (2004). Interpreting Gender in Islam a case study of immigrant Muslim women in Oslo, Norway. Gender and Society, 18(4), 473-493.

Rose, J., Flak, L. S., \& Seabo, O. (2018). Stakeholder Theory for the E-Government Context: Framing a Value-oriented Normative Core. Government Information Quarterly, 35, 362-374.

Rosen, J. (2017). Gender Quotas for Women in National Politics: A Comparative Analysis Across Development Thresholds. Social Science Research, 66, 82-101.

Rosenbluth, F., Kalla, J., \& Teele, D. (2015). The Female Political Career. World Bank Group, Women in Parliament Global Forum, Zurich.

Rowley, T. J. (1997). Moving beyond Dyadic Ties: A Network Theory of Stakeholder influences. Academy of Management Review, 22(4): 887-910.

SADC. (2019). Women in politics and decision-making. [Online] Available: https://www.sadc.int/issues/gender/women-politics/ (o2 November 2020)

Sales, R. (1997). Women Divided: Gender, Religion and Politics in Northern Ireland. London: Routledge.

South African History Online (2019). European Missionaries in Southern Africa. [Online] Available: https://www.sahistory.org.za/article/european-missionaries-southern-africa-role-missionaries (o9 January 2021)

Steimanis, I., Hofmann, R., Mbidzo, M., \& Vollan, B. (2020). When Female Leaders Believe that Men Make Better Leaders: Empowerment in Community-based Water Management in Rural Namibia. Journal of Rural Studies, 79, $205-215$.

StatisticsSA. (2011). Gender Statistics in South Africa, 2011. [Online] Available: http://www.statssa.gov.za/publications/Report-03-10-05/Report-03-10-052011.pdf (20 July 2020)

Thomas, S. (1994). How Women Legislate. New York: Oxford University Press.

Snider, J. (2005). The Failures of E-democracy. Washington DC: American Political Sciences Association.

Sturm, R. E., Taylor, S. N., Atwater, L. E., \& Braddy, P. W. (2014). Leader self-awareness: An examination and implications of women's under-prediction. Journal of Organizational Behavior, 35(5), 657-677.

UN CSW. (2009). Commission on the Status of Women: Report on the Fifty-third Session (2-13 March). Economic and Social Council. Official Records: Supplement No.7.

Vijeyarasa, R. (2020). Women's absence in Sri Lankan politics: Lessons on the effectiveness and limitations of quotas to address under-representation. Women's Studies International Forum, 81, 102371.

Wood, H. J. (2019). Gender inequality: The problem of harmful, patriarchal, traditional and cultural gender practices in the church. HTS Teologiese Studies/Theological Studies 75(1), a 5177. 